\title{
Teaching Islamic Education in Early Childhood by Instilling Values Islamic Aqidah
}

\author{
ARINA DEWI MASITHOH \\ Program Studi Pendidikan Agama Islam, Universitas Islam Negeri Sunan Ampel Surabaya, Indonesia. \\ Email: Arinamasithoh21@gmail.com
}

\author{
Article Received: 12 December $2019 \quad$ Published Article: 01 May 2020 \\ DOI: https://doi.org/10.29313/ga:jpaud.v3i2.5410
}

\begin{abstract}
At an early age, the golden age for children is the growth of intelligence in children because this age child started to vulnerable to increased them in faith and the development and growth physical mental out of the ordinary in phase which gradual. This day and age is a period of the formation of the nature of personality and a child's character. Early age is the most important because of the creation of the children the essential personality. Essential start instruction and correction of the child by religion give education from an early age. If religious education is not the doctrine taught to a child in effect learning early childhood, education by changing civilization embodies the generation who excels in intellectuals religious by instilling religious values and sticks to young kids. In the planting of Islamic values sticks teaching Islamic education having a substantial share. Especially for the developments of the times sure.
\end{abstract}

Keywords: Early Childhood; Education; Values Aqidah.

\begin{abstract}
Abstrak
Golden age bagi anak-anak Usia dini merupakan masa tumbuh kembang kecerdasan pada anak, karena rentan pada usia ini anak-anak mulai mengalami masa perkembangan dan pertumbuhan fisik mental yang luar biasa dalam fase yang bertahap. Masa ini merupakan periode pembentukan watak, kepribadian dan karakter anak. Usia dini merupakan masa yang terpenting, karena masa untuk pembentukan kepribadian anak yang paling utama. Sangat penting memulai didikan kepada anak dengan memberikan pendidikan agama sejak dini. Bukanlah doktrin jika Pendidikan agama diajarkan kepada anak dalam mempengaruhi pembelajaran anak usia dini, melainkan pendidikan dengan mengubah peradaban untuk mewujudkan generasi yang unggul dalam intelektualis serta religius agamis dengan menanamkan nilai-nilai Aqidah kepada anak sejak dini. Dalam penanaman nilai-nilai Aqidah Islam Pengajaran Pendidikan agama Islam memiliki andil yang sangat besar. Terutama bagi perkembangan zaman tentunya berbeda dalam metode pengajarannya, tetapi nilai-nilai Aqidah harus tetap ditanamkan sejak anak berada pada tahapan usia dini. Pendidikan Agama diperkenalkan sejak dini kepada anak berarti telah membentuk pribadi anak yang religius, terutama dalam nilai-nilai keagaamaan yakni Aqidah dan syariat agama.
\end{abstract}

Kata Kunci: Anak Usia Dini; Pendidikan; Nilai-nilai Aqidah. 


\section{INTRODUCTION}

PAUD, an abbreviation of early childhood education, is the earliest education for children started 4-6 years. PAUD reached before the basic education level. Three the PAUD: formal education, non-formal informal or Formal education, on the trail PAUD shaped kindergarten TK (Kindergarten Children ), RA (Raudhatul Athfal), or form or other. Non-formal education, on the trail PAUD-shaped KB (such as community play), park the nursery, or form or other. Informal education, on the trail PAUD shaped like a family or education, education held by environmental residence early childhood, example: held TPQ.

Many experts who made of and growth child in the religion scientific about the foundation the importance of education in early childhood. Relation growth and child development intelligence can not be the development of the brain. In research conducted by Wittrock, she said that there are three brain's systems readily undergoing a rapid increase in intelligence, the children brain the growth in dendrite fibers, synapses relations between complexity, and the division of the in the nerve cell. The sensitivity and insensitive to receive a stimulant when reaching their year 4-6 are golden ages (the golden age for children) to develop their potential. A stimulant indispensable in line with early childhood to be in the process of growth and development of potency in the reached optimally.

Religion, religious education taught in early childhood started by planting Aqidah values as early in educating children, moreover at the age of children golden age on the easier to start learning to interact with the world. Before early childhood, who taught Islamic increased should be introduced first with values Islamic Aqidah. Religion explained that early age is most comfortable to respond or receive things either added, captured by the senses, and even from experience taught by parents to early childhood. Islamic education taught in early childhood to impart Aqidah life Islamic values as guidance, to and if the child has been growing up, development to increase belief and Fear of God.

Which keeps growing in the days of the old school need suitable for the level of education his children still at a young age. Educational institutions like PIAUD, Raudhatul Athfal level are very needed in education for early childhood order to phase. This study mainly focused on studying preschool children called early childhood. The preschool children meant here is early childhood a focused in the education sector.

\section{DISCUSSION}

\section{A. Islamic Education Sense}

Islamic religious education is the work done by an educator (teacher) to form character students, students so that Al-Qur'an and the tradition of AsSunnah (by Islamic teachings). The context of education in Islam was known by Al-Ta'lim, Al-Ta' dib, and Al-Tarbiyah. According to the experts, Islamic education Zakiah Daradjat said Islamic education is the formation of Muslim personality. Moreover, your M. Arifin Islamic education is Muslim businesses with conscious direct and guide the development and growth (ability as essential) possessed a son through an Islamic nation at the utmost point growth and development. According to K.H. Hasyim Asy' ari said about Islamic education, education helps against good intentions and an oriented to experience to approach him. There is also the opinion of Qardawi Islamic education to the meaning, had Islamic education is education for humanity in full, covering the heart and mind, physical and spiritual, Akhlak and his routine and behaviors. It can be concluded from you mentioned above that education is one of the Islamic da'wah Islamic propaganda to be developed in the challenge the continuous will change later, and it is imperative to warn early childhood because of science that growing also to date.

It is the very in assessing religion and apply values Islamic Aqidah certainly in early childhood. Islamic education held early childhood can understand early religion deeply. Although not profoundly child can know some knowledge in religion, properly applied every day, and in all aspects of life. Islamic education is not the doctrine that affects learning early childhood, but education by changing civilization to realize generation who excels in intellectually and religious. Not only early childhood, even from nascent to adult, must also be learned in Islamic education. The importance of Islamic education for early childhood also stated in the paragraph it verse Al-Qur'an an: 
Meaning: "Allah get you out of the wombs of your mothers while you know anything, god gave you hearing and, sight and hearts that you always grateful." (Al-Qur'an Surah An-Nahl: 78).

In exegesis Fathil Qadir, they put forward by Syaikh Dr. Mohammad Sulaiman Al-Asyqar he is they you teachers Islamic University. That when a mom has birth from the uterus that it as a small and does not know, and he grace sight, hearing, and hearts so that they believe in Allah SWT and given to first ungrateful for the good and so that they can know religion and suitable for her life. It is mentioned in Al-Qur'an that education that began when the beginning of life. In terms of views, Islam early childhood education is useful in maintaining growth and development owned by man's son. Fithrah So your spirit who was born by the condition of desires not defiled by her earthly life. In Islamic education, educational objectives on early childhood useful to infuse values, Islam, to children so that the development of early childhood subsequently becomes devout Muslims who believe and devotion to Allah SWT.

\section{B. Early childhood}

Education in the world is often called with PAUD, namely the education level of early childhood. Who referred to early childhood that? Early childhood is the aged son 0-8 years from start to children born into the world so that a period. Growth has stepped in. Many people also argued about the range of the age of early childhood. Some say 3-8 years someone 3-6 year said. Age is the age range and early childhood, in which children from many stimulate what is heard with their ears, seen with her eyes, and excitative with his body. Is early childhood education not widely taught the school Islamic, but Islamic education taught parents home early will gradually be gradual, from things often held by every day to the children will to other new things. And the child has been a period of growth when especially so-called an early age times this child to more active and many play because it is his world, as much action, and chattering. Whatever he will be tending to natural reported to their parents.

The early age in children's growth is often associated with the child's golden age or often called the golden age. This is a phase to optimize the growth and development of the baby. Relates to the development of Islamic education in early childhood. If it is associated with a characteristic, early childhood has its characteristics and typical:

1. Like imagination and do something think

2. Ask any questions and having a great curiosity

3. Time for fastest and easy to memorize

4. Often wonder when doing something new done

5. I want to try something required for vision.

It is characteristic of early childhood often incline to his own because they started to know many things in her prime. So it is okay if they do things that allow parents to worry because they have not fully distinguished good, evil deeds. The more it is staggeringly, the child he will know and starting to see if the act itself right or wrong from the knowledge alone.

Early childhood education not been education held for facilitating growth and child development thoroughly and intelligence ( potential ) or emphasize the development of early childhood own personality. Early childhood education is given to developing the growing a personality in optimizing the. Hence, they must take various Activities they can develop various aspects of education for the development of early childhood, covering cognitive language, social, physical, and motor emotion.

\section{Educational Institutions to Early Childhood}

The level of education is useful for the presence of an educational institution on a level equivalent to early childhood. Indonesia has been regulated in act Republic of Indonesia number 20 the year 2003 on the national education system education level to be considered equal early childhood program and held through the formal program, like the garden Raudhatul Athfal, in the non-formal program like the play park and child care, and the informal education environment family and community.

PAUD organized to help developing potential early childhood from birth to by the age of 6 years old (toddlers), covering the aspects of physical and nonphysical, by giving a stimulus for early childhood in the development of physical and 
motoric (motor coordination smooth and bristly), cognitive (power think, power copyright, emotional intelligence, and intelligence spiritual, language, and communication), psychosocial (attitudes, emotion, behavior) morality, and the ways of religious), to achieve the development of optimal provide an ample opportunity to explore and learn inactive, to make preparation the level of education next.

According to a section of 28 , the act of Sikdinas no. 20 the year 2003 verse is 0-6 1 year. Scope education for early childhood, the formal too early childhood 4-6 year :
a. Kindergarten (TK)
b. Raudhatul Athfal (RA)
c. Bustanul Athfal (BA)

The non-formal to early childhood :
a. Playgroup
b. The care of a baby sitter
c. The child family development

The informal :
a. Family
b. Friends or relatives.

There are several educational institutions in Indonesia to early childhood that has been there to them among the public at large the garden of the children and Raudhatul Athfal. The child is a formal education unit to conduct education for children aged to years, 4-6 the children 2 divided into their allotments are a study group for children aged 4-5 years and for children age group B 5-6 years. One of the early childhood education for non-formal education is playgroups. Playgroups hold education programs and welfare programs for children aged 2 to 4 years. Besides the play, early childhood education on a track non-formal education park is the nursery, which runs programs and education to early childhood and welfare child development from age born ( 0 age ) to age six years. Formed in education formal kindergarten level or shortened by kindergarten early childhood education age year ( 46 ). Emphasis education curriculum stimuli to giving early childhood education to help physical and spiritual growth and development in the child can lead to further education. Under the level of education, informal religion education is Raudhatul Athfal or more often called RA. RA equivalent to kindergarten, the curriculum different but more basic religious to religious. In Indonesia, not to seek the education kindergarten and RA. However, in the development of education, many primary schools for certification for their students who register must pass TK or RA beforehand.

A characteristic of informal education :

1. Not held specifically

2. Not programmed in particular

3. The unspecified time long learning

4. The method used informally as the creativity of teachers

5. Not held the assessment and evaluation

6. Stay shade the government. This means not held by the committee

7. Environment place education was not reserved exclusively.

Curriculum lessons learned early childhood education level :

1. Religion

2. Of total clarity and the language whether for use

3. Read ( know character and spelling ), writing and arithmetic

4. Learned singing

5. Socialize at, family environment relatives and friends

6. Skills

To create the copyright children and encourage learning to an early age, early childhood education introduces the whole range of the sciences by approaching art, value, and language, and independence of that the child can learn skills in creativity.

\section{The role of teachers and parents in infuse values Aqidah Islam in early childhood}

In the religion Islam eminence to teach values, Islamic Aqidah must be started from an early age. An early stage in educating children is by instilling values Aqidah before the child taught how to Akhlak Islamic. Has become the parents and teachers to keep the educator at an early age of numerous irregularities. Besides infuse values Aqidah, the parents and teachers educator also must able to maintain Aqidah children start an early age of everything containing shirk or deed pagans. 
The first thing the old to introduce Aqidah value of Islam is by teaching believed in God the already mentioned in unity faith first, namely believe in God, namely believe that he is in and permanent. When the child has been made her believe whom, so children will start thinking that every done will supervised by his who created them. We need to teach children to continue to believe and believe in God. Teach the child at an early age to believe in God can be applied by the parents in the daily child and taught to carry out the worship of the prayer, fasting, charity, and do charity, including in education Islam from the realization of the deity. Stimulation received the son of teaching and sent this makes an easy to explore as more religious.

The role Is needed for the parents and teachers' educators in early childhood. The role of a parent as the personality, it certainly through education, the moral and spiritual. When in an Islamic school, or school, parents for early childhood was the educator teacher. As has been stamped on an introduction that Madrasah (Islamic school) for early childhood not only formally but also one nonformal and the park education Al-Qur'an, playgroups a study group and others. In building independence on the child to education, this was very consistent the role of older people in all learning for the parents and teachers educator always over new things that does an early age because of age who early need a lot of supervision and teaching about Akhlak good and behavior that courtesy toward anyone, already known and the new person known by the son. Many assumed by parents' activities early childhood at the school is the job of teachers entirely. Moreover, that is not true, portions early childhood education the most are when a kid collaborates with their parents. It is not wrong for parents to teach children who are aged early about all the things that progress.

\section{E. Islamic Aqidah teaching values to children at a young age}

Aqidah Islamic, what sure, the know whom he has one Allah. In terms of substance, Allah is indeed one of the nature of and a form his. Safety and the joy of life in this world or the hereafter will be Aqidah. The messenger whom he has sent to his son has called for strong Aqidah teaching using imparting an understanding of old child Aqidah since early. Allah said in Al-Qur'an:

Meaning: "And Ibrahim has bequeathed the mother's words to her children, so does Ya'qub. (Ibrahim said): "O my children! Indeed Allah has chosen religion for you, so do not you die except in Islam. "(Al-Qur'an Surah Al-Baqarah verse 132).
Teaching religious values in early childhood in terms of Aqidah allows the need for methods that can interact and socialize children with children's needs and interests. Teachers and parents can not force children to be directly taught about the values of religious Aqidah but must be with methods and approaches. Before parents and teachers choose and apply the method, you should first understand the method used. In instilling the values of religious Aqidah in early childhood, the methods vary as much as through storytelling, inviting singing, and playing. Teaching Aqidah values in Islamic religious education to early childhood has several stages, namely:

1. Introduce early childhood with the Five Pillars of Islam and its understanding

2. Give an example of carrying out the pillars of Islam

3. Introducing early childhood with the Five Pillars of Faith and its understanding

4. Give examples of carrying out the pillars of faith in daily actions

5. Teach young children to mention hijaiyyah letters

6. Introducing early childhood with the short Surahs contained in the Al-Qur'an and its meaning, so that early childhood will be stimulated to memorize some of the verses indirectly in the Al-Qur'an.

From some of the stages above, teaching can be taught to young children as creatively as possible Parents and teachers in the school environment should be able to attract the attention of early childhood. Invite him to play and give songs that are easy to memorize the values of Aqidah listed in the teaching phase above. In instilling the values of Islamic Aqeedah, of course, it must get the most attention from teachers in the madrasa environment and kindergartens (TK), Raudhatul Athfal (RA), learning parks, or PIAUD. Education in early childhood, based on the inculcation of Islamic Aqidah values, aims to form children with Islamic personality as the foundation of planting strong Islamic Aqidah. When children already have a strong Aqidah, children begin to develop their thinking power and be kind to people they know in their lives. Personality possessed by early childhood is to have advantages in many ways so that the child can be said to be a superior child that is responsive, intelligent, healthy, and easy to interact socially. Early childhood who are directed on how to behave and think based on the values of Islamic Aqidah and have various abilities and skills used for daily life. The function of instilling the value of faith in early 
childhood is as a provision for their lives up to the future. The main capital in developing children's faith, especially at an early age that runs at the golden age (golden age) is spiritual intelligence. Spiritual Intelligence (Spiritual Quotient) is one of the main factors of children's various intelligence. The function of instilling the value of faith in early childhood is to provide their lives up to the future. The principal capital in developing children's faith, especially at an early age that runs at the golden age (golden age) is spiritual intelligence. Spiritual Intelligence (Spiritual Quotient) is one of the main factors of children's various intelligence.

In Islam, Education about Aqidah or monotheism education must first be taught to children starting from an early age. The first thing taught by Luqmanul Hakim to his child is stated in the verses of the Al-Qur'an not to associate partners with Allah. As the initial basis of all Islamic education processes, this is the urgency of the values of Aqidah, which must be taught in Islamic education. That teaching of science must be accompanied by religion because it is a religion that has absolute truth and good life values. According to Albert Einstein, science without religion is paralyzed and religion without science is blind in his dialectical views.

Instilling Aqidah that is strong in teaching Islamic Aqidah values in early childhood must combine the three elements of intelligence: emotional intelligence, intellectual intelligence, and spiritual intelligence. Later parents and teaching teachers can make children a generation of religious intellectuals who are civilized because they have good moral values and should start from an early age because when children reach stages in the age range of $0-8$ years, that is when the foundation for success a child is built to instill strong Islamic Aqidah values.

\section{F. Aqidah Values are Implanted}

Islam is a life value that must be instilled early on and must be the foundation of life. As for the teachings of Islamic Aqidah, some material taught to young children includes material faith or Aqidah, AlQur'an, figh/worship, morality, and historical dates. In studying the material of early childhood faith introduced to religion more deeply through basic contexts, such as the nature of Allah for Allah, the obligatory nature of God numbering 20, the impossible nature for Allah numbered 20, introducing the names of Prophets and Apostles along with the obligatory and impossible qualities, introducing angels and their duties, and teaching to believe in them.
Furthermore, in the material Al-Qur'an. Many early childhoods have been understood about how to read hijaiyyah letters, write Arabic letters, and memorize Al-Qur'an letters. However, teacher educators and mentors must always be patient in teaching the Qur'anic material; indeed, the abilities of each child are different. Teaching can be modified by playing and singing so that children are better trained to remember easily.

Jurisprudence/worship related to learning the values of Aqidah in early childhood education is taught by practice directly. Often found in a child's garden, Raudhatul Athfal children are taught the practice of worship, ablution, wear Mukenah or gloves, and procedures for prayer. Teaching children and motivating them to worship must use creative methods to not be bored when practicingfor example, the prayer command. Rasulullah Muhammad SAW reminded in the Hadith of Abu Dawud that parents must order their children to pray when they are ten years old. If they do not want to, then they have to get hit.

Akhlak dramatically affects the nature and behavior of children. In this millennial era, especially for parents, they must always control their children because the bad moral influences from the outside environment often affect children. From the Prophet's time to the millennial era as now, children who have good character always spontaneously people will ask "whose child is this" as a form of appreciation to their parents. The child's character is inseparable from the role and parental education. Errors in education can make children grow not as expected, especially in the 'present era' as it is today. Many parents are so permissive in educating their children. As a result, children grow up to be a generation that causes many losses. Of course, all parents want their children to be in the tough generation. Both physically, morally, especially morals. This can be realized if parents apply a strict attitude in educating their children. They are applying good moral behavior, both in saying and behaving. In the process of education, firmness is essential if it relates to religious teachings.

History dates taught to young children to take wisdom and role models to be associated with life today. For parents or teacher educators in institutions, schools, study groups can provide insight with the method of telling young children to stimulate to know the purpose of history. Many kinds of history books are packaged by the style of early childhood and printed explicitly for the range of early childhood. 


\section{G. The Potential of Children in Planting Aqidah Values with Islamic Education}

Education nowadays sometimes only focuses on developing children's intellectual intelligence abilities and separating science from religion. So the result is children who are smart but are empty of religious religious religious values. In this era, substantial problems often occur, namely viewing children's $I Q$ paradigm as a unit of ability. Educational outcomes are only determined by the size of IQ test achievement scores. The Research Team conducts Research that IQ (Intellectual Quotient) on the child's ability or intellectual intelligence of children since the beginning of growth and development until now is glorified by parents and education practitioners, the reality that occurs is not entirely appropriate in supporting the success of a child later, many parents and teacher educators who have succeeded intellectually to prove with the achievements or report cards and good test results. That is why intelligence that exists in early childhood needs to be developed. The latest scientific research findings show that early childhood intelligence also consists of emotional intelligence and spiritual intelligence in addition to intellectual intelligence.

Emotional intelligence is the ability to recognize our feelings and others' feelings and how children can recognize who they are. The ability to motivate yourself and manage emotions well in yourself and in relationships with others other than family and close relatives who live around these early childhood environments. In comparison, the purpose of spiritual intelligence is intelligence that relies on oneself to do with wisdom outside the ego or the conscious soul. This intelligence is used to find out the values that exist. Intelligence like this, which is related to God's appreciation and religious values, in Islam, is called Aqidah. Education must be instilled true Aqidah to combine the three elements of intelligence, including emotional intelligence, intellectual intelligence, and spiritual intelligence. So the child has civilized Akhlakul Karima creates a generation of religious intellectuals, because this must begin to educate children at the earliest possible age when children are 0-8 years old, that is the cornerstone of parents' success in building the religious intelligence of a child at an early age. In a hadith, the Prophet Muhammad said: "demand knowledge from the cradle to the grave."

The Hadith explains how important it is that one must learn early on, even from the cradle. In Islam, this early education is the foundation of scientific education. From an early age, children must be given various knowledge (in various stimulants/stimuli). Giving education to young children is like carving on a rock that will not disappear and will even stick forever. Education in early childhood will be inherent in the soul of a child until he grows into adulthood. At this age of education, it becomes the foundation for further children's education to be sustainable. The success of early childhood education plays a big role in the success of children in later years. Early childhood is a different individual, unique, and has its characteristics according to the stage of age. Early childhood is a period of stimulation of all aspects of development that play an essential role in the task of further development.

It should be realized for parents and teacher educators that the early days of a child's life are the essential times in a child's life span. At this time, the child's brain growth is experiencing very rapid development (Explosive). In the first year, development in early childhood is significant to determine the child's quality in the future. In children aged four years, children's intellectual development has reached $50 \%$, at the age of 8 years, child development reaches $80 \%$, and later, when reaching the age of 18 , the child's development has reached $100 \%$.

Aqidah learning and education should not be understood as belief in the Pillars of Faith only, namely faith in Allah, angels of Allah, Allah's Books, prophets, the last day, and qadla-qadar only, but Aqidah must also be understood as carrying out all that has been ordered by Allah and worship him, as well as how to apply the values contained in the Aqidah that we believe in so that in teaching children at an early age we can implement it well because Aqeedah will guide us always to obey Allah and believe that Allah rules are the most correct. Aqeedah will always guide us to obey Allah's commands. So this is where the concept of education to early childhood must be conceptualized well. Early childhood education is taught to realize those qualified in science and are empty in ethics and morals, but form qualified human beings both in IMTAQ and its Science and Technology.

Potential in children is an essential ability possessed by children, which is very likely to be developed. In essence, potential as a capability that continues to be developed even better in the development and development of children, especially at an early age. The potential of early childhood in learning science has extraordinary stages. Sound brain growth stages overgrow and are ready to be filled with various new information and experiences. A study shows that early childhood is the window of opportunity. At times like this, the child's brain is like a sponge that can absorb fluid. In 
order to absorb, the sponge must naturally be placed in water.

This water is likened to experience. Herein lies the role of parents in charge of providing children experiences to introduce them to activities of interest, such as introducing to hobbies or things that children like. If, since a baby, the child has been stimulated by various stimuli, the cerebellum will absorb. For example, if the child's ability to speak is not often stimulated, the child will experience delays in speaking, and his verbal ability will be stimulated well. Associated with children's potential in inculcating Aqidah values, of course, if parents and teachers use stimulation well to early childhood, the results would also be useful if done according to acceptable teaching methods.

\section{H. Get to know the character of early childhood in Religious Education in the Millennial Age}

In this growing age, related to the character of early childhood, the characteristics of children in the world of education are used as a period of play, a period of fun, and a period of learning. Almost all educational institutions that overshadow early childhood levels involve religious education in the teaching curriculum. In the previous sub-chapter, it has been mentioned about the concepts and methods of teaching Islamic religious education in various institutions and schools equivalent to early childhood. To find out the characteristics of teaching Islamic religious education to children, a process is needed its development. Its function is to know the character and behavior of children in the development of increasingly modern times. Not only struggling with playing even having fun, in fact, but many characteristics of early childhood can also be observed, namely:

1. Having a unique imagination Imagination is a child's ability to create objects or events, but only in his imagination.

\section{Egocentric}

This can be seen and observed from the attitude of children who are often still fighting over something when they want something they want, angry or crying when their desires are not obeyed, and force their desires according to their ego.

3. Happy to fantasize

Fantasy is a child's ability to form a new response with an existing response, and then there is trying to express what he did.

4. Active and energetic

The child's development period is always active in doing many activities until the parents are exhausted in controlling the child, especially if they are energetic in their activities.

5. Has a short concentration power

In early childhood, the range has a very sharp focus and attention compared to teenagers or adults. The attention of young children will be easily diverted, especially those that can attract attention. It is difficult to control the view to focus on what is taught.

\section{Challenges in teaching Islamic religious education in early childhood}

Various systems and levels, from time to time, teaching Islamic education are always experiencing challenges. As in history, various advances and lags behind Islamic education will occur. Internally and externally answer the various problems of the times and challenges faced. Today's challenges are very much different from the challenges of Islamic education as existed in the classical and middle ages. The challenges of education in classical and medieval times are quite heavy, but ideologically and psychologically more easily overcome. Internally, Muslims in classical times are still fresh, with the source of Islamic teachings in their life very close, and the spirit of emigrating in struggling to advance the teachings of Islamic fii sabilillah is still powerful. Externally, Muslims are still unable to deal with serious threats from other developed countries.

However, the challenges faced in Islamic religious education have given birth to various new paradigms. Covering the vision, mission, goals, curriculum, teaching and learning process, educators, students, institutions, management, infrastructure, education is now experiencing a huge change. Supposedly, with his long experience, Islamic education can provide the right answers to these challenges. To answer challenges like this, Islamic education requires reliable human resources, committed to holding fast to the Qur'an and As-Sunnah in building a generation superior. In educating early childhood with Islamic education, it takes a healthy energetic because more and more years, the potential for children's thinking is changing according to the era in which he was born. Lately, many parents pay less attention to education for children, especially in early childhood.

Though education becomes an essential and fundamental thing for children for their future, parents should pay more attention to this modern and digital era of globalization and be smarter in choosing good education for their children, especially early childhood education. Islamic 
education is an essential education instilled in children because it plays an essential role in shaping good character and personality for children. It is better if Islamic religious education is taught and instilled in children from an early age because remembering the many cases in children due to moral decline and flawed character. In this case, the parents' role is significant in teaching and instilling good character and morals in forming good character and personality for a child.

Especially in answering the challenges of teaching Islamic religious education for early childhood. Children are likened to white papers that are still clean, which can be written with anything. In this case, parents have a significant role in the continuity of children's education because parents are the initial and essential educators of forming a child's character. As explained in the section on the role of parents. The good and bad behavior of children is determined by how parents teach Islamic values to their children.

\section{J. Early Childhood Education in Islamic Perspective}

In Islam's perspective, perspective is the view that everything that is carried out certainly has an excellent legal basis and comes from aqliyah and naqliyah grounds. Likewise, with the implementation of education in early childhood. Implementation of early childhood education Relating to the Word of God stated in the Al-Qur'an which means: "And God took you out of your mother's stomach in a state of not knowing anything, and. He gave you hearing, vision, and heart so that you are grateful" (An Nahl: 78). Based on the understanding of the verse above, it can be understood that the child is born in a weak, helpless state and does not know anything (does not know). However, Allah equips the newborn child with hearing, vision, and conscience (that is the reason, in the opinion that the center of faith is in the heart). In another opinion is the brain. Humans can distinguish between everything, which is beneficial and which is dangerous. Little by little, these Senses and Abilities are obtained by someone gradually. The greater the child's stimulation also increases the ability of hearing, vision, and reason until he arrived at the ripe age and mature.

\section{CONCLUSION}

Religious education in early childhood in Islam begins with the inculcation of the values of Aqidah as initial stage in educating children, moreover at the age of children who reach the age of golden age of children is more comfortable to start interacting with the world of learning. Before being taught Islamic morals, early childhood should be introduced first to the values of Islamic Aqidah. Islamic religious education attempts educators to shape students' character by Al-Qur'an and AsSunnah (by Islamic teachings). At an early age, the term Golden Age is often associated with optimizing children's growth and development.

The nature of early childhood education is education organized to facilitate the growth and development of children as a whole or emphasize the development of all aspects of early childhood personality; in teaching religious values, especially Aqidah in early childhood, the need for methods that can enable young children to interact and socialize with the needs of children's interests. Some of the material taught to young children in teaching Islamic Aqidah includes faith or Aqidah, the Al-Qur'an, figh/worship, morality, and historical dates. Education must be instilled true Aqeedah to combine intelligence, including emotional intelligence, intellectual intelligence, and spiritual intelligence.

Early childhood education in Islam This is the foundation of scientific education. Children must be given various knowledge (in the form of various stimulants/stimuli). Providing education to young children is like a presupposition "like carving on a stone that will not disappear even stick forever." Islamic religious education is an essential education instilled in children because it plays an essential role in forming good character and personality for children. Islamic education is good if it is taught and instilled in children from an early age, given the many cases that occur in children due to the deterioration of morals and destructive character. The role of parents, in this case, is significant to teach and instill good morals and morals in the formation of good character and personality for a child, especially in answering the challenges of teaching Islamic religious education for early childhood.

\section{REFERENCES}

Amin, Rifqi. (2015). Pengembangan Pendidikan Agama Islam. Yogyakarta: LKIS Pelangi Aksara.

Anonim. (2015). Jurnal Madaniyah Pembelajaran Pendidikan Agama Islam Anak Usia Dini, edisi ke VIII Halaman 5.

Djoko Adi dan Anies Listyowati. (2017). Memahami PAUD secara singkat. Depok: Prenadamedia Group.

Guslinda dan Rita Kurnia. (2018). Media Pembelajaran Anak Usia Dini. Surabaya: CV. Jakad Publishing. 
Golden Age: Jurnal Pendidikan Anak Usia Dini, Volume 3 Nomor 2 (Desember 2019)

ISSN 2549-8371 | E-ISSN 2580-5843

ARINA DEWI MASITHOH / Teaching Islamic Education in Early Childhood by Instilling Values Islamic Aqidah

Hadisa Putri. (2016). Konsep Pendidikan Anak Usia Dini Dalam Perspektif Islam Jurnal Khazanah.

Jurnal Studi Islam dan Humaniora Vol. 14 No. 2. hal 215.

Iswidharmanjaya, Derry. (2006). Bila anak usia dini bersekolah. Jakarta: Elex Media Komutindo.

Mahfud. (2015). Pembelajaran Pendidikan Agama Islam, Yogyakarta: Deepublish.

Mashar, Riana. (2015). Emosi Anak Usia Dini dan strategi perkembangannya. Jakarta: Kencana Prenada Media.

Nizar, Syamsul. (2001). Pengantar Dasar-dasar Pemikiran Pendidikan Islam, Jakarta: Gaya Media Pustaka.

Rianti, Ayu. (2014). Cara Efektif Mengenalkan Rukun Iman pada Anak Usia Dini. Jakarta: PT gramedia.

Suryana, Dadan. (2016). Pendidikan Anak Usia Dini Stimulasi dan Aspek Perkembangan Anak. Jakarta: Kencana.

Suyadi. (2010). Psikologi Belajar Paud. Yogyakarta: Pedagogia.

Tim Peneliti Balai Penelitian dan Pengembangan Agama. (2008). Paradigma Baru Pembelajaran Keagamaan di Madrasah Ibtidaiyah. 